\title{
Editorial: We got lucky - now we are going viral
}

\author{
Dr Malcolm Sutherland (deputy editor-in-chief)
}

On 27 July 2014, my co-editors-in-chief and I, along with four representatives from Springer Science \& Media LLC and Apress, signed a purchase agreement, certifying that Springer would buy and take over The Computer Games Journal. The financial transactions were completed a few weeks later. Starting in 2015, future volumes of The Computer Games Journal (as an Apress title) will be copyright of Springer, and will be distributed online across Springer's vast online networks and citation databases. As soon as the first quarterly edition is published, hopefully in March 2015, this journal will go viral. It will be brought to the attention of countless universities, colleges, institutes and private company subscribers throughout the world.

Let me make something abundantly clear. I am not trying to be smug when I write this - far from it. Hence the very colloquial title of this editorial, for this last independent journal edition. Just before we published the earlier edition this year, I penned the editorial, 'Taking The Computer Games Journal to the next level', wherein I declared that the time had come to make this journal more visible and professional, and that we were seeking a university, or journal publisher or online data-disseminating organization, which might take over this journal. Back then, it did not even cross my mind that the likes of Springer would make any serious advances, let alone acquire this publication. That previous editorial was a gamble.

Hence the seven-month lull between the earlier 2014 edition, and this one. And what an edition this has turned out to be. Five months ago we had two submissions in our inbox. Then, shortly after we announced in June that Springer will be taking over the journal, we received a surge of papers and student dissertations. This double edition - not to mention the Springer purchase - has surpassed my expectations. The geography alone is breathtaking: we have processed dissertations, chapters and essays written by people in California, Austria, Wales, India, Denmark, the USA, and even someone from The University of Cambridge. Of course, we have not forgotten our roots, and it is fitting that we have included a systematic literature review by a researcher at UWS Paisley, plus some short essays by industry professionals here in (what nearly became an independent) Scotland.

The issues discussed in this year's student edition contrast with those in the 2012 and 2013 student editions. Previous student papers mainly focused on games technology (graphics, audio, etc.) and on players' psychological and emotional responses. This year's offering is more leftfield, examining aspects of videogames and related entertainment from a considerably different slant. One paper challenges the conventional game design process, and proposes a time-saving solution. Another paper examines the sociological touchstones of a film, but from a videogame analyst's perspective. Another paper discusses why televised wrestling has not translated successfully into the videogame medium; it describes how wrestling is not your average competitive sport (it is in fact a dramatic choreographic tale of good versus evil), and that the stories are written by the fighters as they go along. Another paper focuses on the navigation perceptions of a text game environment by blind players. These are just four examples taken from the eight papers, all of which are groundbreaking.

Furthermore, following advice given to us at the Springer offices in London, we decided to combine this year's student edition with a special edition to form this double edition, which has proved to be an exciting finale as this journal changes from a small independent title into a Springer title. We wanted this year's special edition to be as radical, controversial and useful as last year's special edition on games entrepreneurship. So, over a few coffees with two people from Apress, my co-editors and I 
decided to pose the short but tough question, "What (do you think) is missing from games?" Once again we decided to bend and break a few rules. We invited leading professors, games developers and experienced industry consultants to write very short essays, and tackle that question using their own knowledge, ideas and chips on their shoulders. The responses make for compelling reading. One author (a well-known ex-games company director) laments that building games and releasing them online is becoming far too easy, and has resulted in a flood of unimaginative duds, which are tarnishing the games market stall. Another author calls on games designers to create 'emergent play' games where the rules and limited options in game levels can be challenged and altered by players. (So - rather than the player having to travel from $A$ to $B$ along a set trajectory, fight aliens $C$ and $D$, and collect items $F$ and $G$ at point $B$ - the player can step aside, create a new itinerary and try something different.) Another accomplished academic challenges the notion that games degrees do not 'belong' in a liberal arts category.

I should mention at this point that once this journal becomes fully integrated into the Springer system, we shall have to revert back to a more formal structure, in terms of the length, contents, format and referencing of the submissions. There shall be no more student dissertations or special editions, and restrictions shall be placed upon literature reviews, long quotations, giant image files and appendices. I should also remind readers that this edition and all the previous editions of The Computer Games Journal have not been purchased by Springer, and so all the papers in the 2012 - 2014 volumes shall remain copyright of the authors, and will be preserved as an online archive under the slightly different URL, www.computergamesjournal.info.

However, I am still coming to terms with this sudden change, after five years of my struggling to launch projects, companies and products. How did we end up here?

I suppose it is worth recounting the whole TCGJ story. At the beginning of 2010, I launched TuDocs Ltd, left a security job, and launched a careers website for computing students. 18 months later the website was closed down, and the company was restructured. Exactly three years ago, John laid the foundations for this journal, but as one feather on the TuDocs cap. Tony Maude was appointed sole editor-in-chief and he went to work, sending out calls for papers, and communicating with board members and authors. Suddenly, in early April 2012 he suddenly suffered a stroke and was briefly put out of commission, and I stepped into the breach. Two months later TuDocs Ltd went to the wall and was closed down. The journal seemed to be doomed...but we had just published a wonderful first edition. In July 2012 Tony, John and I decided to resuscitate this journal, and we cobbled together a second edition featuring student essays and dissertations - thus setting the precedent for later student editions. During the winter months of 2012/2013, something curious started to happen - papers from around the world, from Malaysia, Canada, the USA, Australia, Greece, and even Malta, started to arrive at our inbox. The third edition (vol. 2 ed. 1, 2013) was a vindication of our decision to save the journal. We launched our papers on Scribd.com and Issuu.com, and clocked over 10000 'reads' before the year was out.

However, this time last year, I harbored grave doubts about the long-term future of The Computer Games Journal, even though we had the loyal support of around a dozen editorial board members, and were still receiving a small stream of papers from around the world. I need not explain the reasons why, for they are all detailed in my previous announcement-styled editorial. Suffice to say, in March, out of nowhere, we received a speculative email from someone at Apress who is working for Springer. In April, both he and an Apress colleague met with Tony, John and me. The rest is history.

We were found. We got lucky. And we will now be going viral. 
This is similar to the story told by many (of the very few) successful games entrepreneurs who spent years toiling in a horrible day job and building their games in a bedroom or basement. Then one day, they built THAT game... and the game went viral. It sold like hot cakes and became a 'classic'. After years of pointless meetings, failed projects, discredited ideas, unanswered job application forms and other ups and downs in my struggle for existence, I have learned that the reason for success is mostly due to 'reasonable' chance. If you plan, prepare and work hard, you stand a much better chance - but it is still largely down to chance. It sickens me when I hear people tell me that they "got to where they are today" simply by "working hard". That formula would make every Subway general assistant, Nike sweatshop worker, school teacher, games developer and postdoc-cum-lecturer a millionaire. Real economics is mean, unpredictable and unfair.

First of all, you have to be in the right place, at the right time, with the right ideas, with the right attitude, with the right amount of money/time/resources, with the right experiences, the right friends (very rich, powerful ones), and the right software versions on the right machines. Feel free to contribute to this list. Secondly, and much more importantly, people do not become successful entirely and solely through their own efforts. If someone else doesn't like your product, you won't become rich. If you can design a product but need someone else to do the hard bit of assembling and distributing it, then your "I didn't get to where I am today" boast doesn't have a leg to stand on. Especially in the journal writing business, it is good etiquette to acknowledge and measure the contributions made by other people.

I will state that the two Apress managers who discovered The Computer Games Journal did stumble upon this through a random internet search. However, this journal was discovered, favoured, purchased and taken over by Springer, thanks to the voluntary efforts of dozens of editorial board reviewers, friends, colleagues, and the many authors here in the UK and abroad, who have been promoting this journal, sharing information, and drafting or reviewing papers. I alone have spent several thousand hours working on this journal. All these people have spent far more time by comparison, in making this journal what it is today. Not to mention the signatories from Apress and Springer who chose to take a risk, and who spent hours in several meetings with Springer's top brass advocating on our behalf.

It is therefore appropriate to bid a fond farewell to those ex-board members who helped us, but who have moved on. In April we restructured the editorial board, and there were some notable academics and games industry professionals who had completed reviews and promoted this journal, but who have since departed - people such as Alonzo Addison, Gordon Dow, Simon Meek, Laurence Emms and Walter Patterson. There were also a few Blitz games developers who backed this journal, but who sadly disappeared off the radar when their company closed down. Dr Tony Maude, who deserves much of the credit for the success of this journal's first edition, and who has reviewed many subsequent papers and contributed some intriguing ideas and advice, is now leaving the building.

Of course, this journal is not quite 'there' yet. It will take a few more months before we release the first Springer-owned edition, and at least three years for this journal to become a leading title. We as editors, peer reviewers, authors and promoters - all owe it to one another and to future readers to make this happen. 